\title{
消毒剤によるバキュロウイルス性中腸腺壊死症 $(\mathrm{BMN})$ ウィルスの不活化効果
}

\author{
桃山 和 夫*1 \\ (1988 年 12 月 9 日受付)
}

\begin{abstract}
Virucidal Effect of Some Disinfectants on Baculoviral Mid-gut Gland Necrosis (BMN) Virus
\end{abstract}

\section{Kazuo Момочама}

Yamaguchi Prefectural Naikai Fisheries, Experimental Station, Yamaguchi 754, Japan

(Received December 9, 1988)

\begin{abstract}
Virucidal effect of some disinfectants on baculoviral mid-gut gland necrosis (BMN) virus prepared from frozen naturally infected post-larvae was examined by infectivity experiments using larval and postlarval kuruma shrimp, Penaeus japonicus.

BMN virus was inactivated by contact for 10 minutes at $25^{\circ} \mathrm{C}$ with $5 \mathrm{ppm}$ as active principle-concentration of chlorine, $25 \mathrm{ppm}$ as active principle concentration of iodine, $100 \mathrm{ppm}$ of bezalkonium chloride, $100 \mathrm{ppm}$ of benzethonium chloride, $0.5 \%$ of formalin and $30 \%$ of ethanol.
\end{abstract}

クルマエビの種苗生産時に発生するバキュロウイルス 性中腸腺壊死症 (BMN) は, 病原体がウイルスであり, かつ, 死亡率が極めて高い疾病であることから, 病害対 策としては予防対策が特に重要である。本症と同属ウイ ルスによって起こるカイコの核多角体病 (NP) では, 龺 室・亘具等の消毒に各種消毒剤の使用が効果を挙げてい る(福原，1979)。しかしながら，クルマエビ類を含む甲 殼類由来のバキュロウイルスに対する消毒剤の不活化効 果は未だ全く調べられていない。

今回, 筆者は前報 (MoMOYAMA and SANO, 1988) で 確立したクルマェビ稚仔の浸漬接種による感染実験方法 を用いて, 数種消毒剂による BMN ウイルスの不活化効 果を調べたので報告する。

\section{材料および方法}

\section{1. 供試クルマエビ}

山口県内海栽培漁業センターで種苗生産されたミシス から P-4 (4 日齢のポストラーバ) までのいずれかの発育 期にある健康な稚仔を用いた。これらの稚仔は BMN ウ

*1 山口県内海水産試験場

*2 桃山和夫 - 佐野徳夫; 昭和 63 年度 日本魚病学 会大会, 講演要旨, p. 22.
イルスに対して高い感受性を示すことが桃山・佐野*2 に よって明らかにされている。

\section{2. 供試ウイルス液}

サンプルビンに小分けされ, $-80^{\circ} \mathrm{C}$ で $1 \sim 3$ 年間凍結 保存されていた同一群由来の BMN の自然発病エビ $1 \mathrm{~g}$ 約 400 尾 (平均体重 $2.5 \mathrm{mg}$ ) に隇菌海水 $10 \mathrm{ml}$ を加兄 た後, 前報 (MOMOYAMA and SANO, 1988) 飞従って調整 されたホモジネート濾液 $(450 \mathrm{~nm})$ をウイルス液として 用いた。

なお，本ウイルス液のクルマエビ稚仔に対する浸漬接 種による感染力価は, クルマエビの発育期によって多少 異なるが, $10^{-5}$ から $10^{-7}$ の範囲にあった。

\section{3. 供試消毒剈のウイルス不活化方法}

用いた消毒剤は塩素剤 (ピューラックス; 次亜塩素酸 ナトリウム $10 \%$ 含有), ヨード阂 (イソジン; ポピドン ヨード $10 \%$ で有効ヨー素 $1 \%$ 含有), 逆性石けん (オス バン; 塩化ベンザルュニウム $10 \%$ 含有, ハイアミン; 塩 化ベンゼトニウム $10 \%$ 含有), ホルマリン (ホルムアル デヒド $37 \%$ 含有), およびェタノール (エチルアルュー ル99.5\% 含有) の 6 剂とし, BMN ウイルスの不活化 方法は以下の手順に従った。 


\section{塩素郕およびヨード片}

海水 $100 \mathrm{ml}$ とウイルス液 0.1 または $0.5 \mathrm{ml}$ を入れた 三角フラスコに, 各消毒剂 (有効濃度を子め正確に分析) を Table 1 に示す所定の濃度となるように加えて混合 後, 10 分間静置して作用させる。直ちに予め求めておい た必要量の N/10 または $\mathrm{N} / 100$ のチオ硫酸ナトリウム水 溶液を加えて中和し消毒剤の作用を停止させた後, 海水 $900 \mathrm{ml}$ を入れたビーカーに移す。

なお，消毒剤添加後の海水の $\mathrm{pH}$ は, ヨード剂では無 添加海水の 7.95 から $1 \mathrm{ppm} の 7.92,5 \mathrm{ppm} の 7.91$, $10 \mathrm{ppm}$ の $7.88,25 \mathrm{ppm}$ の $7.80,50 \mathrm{ppm}$ の 7.72 へと 若干の低下がみられ，塩素剂では $1 \mathrm{ppm} の 7.98,5 \mathrm{ppm}$ の $8.08,10 \mathrm{ppm}$ の $8.18,50 \mathrm{ppm}$ の $8.56,100 \mathrm{ppm}$ の $8.63,200 \mathrm{ppm}$ の 8.72 へと上昇した。

\section{逆性石けん，ホルマリンおよびエタノール}

所定量の海水 (ウイルス液と消毒剤を加えて $10 \mathrm{ml}$ と なる）を入れた試験管にウイルス液 $1.0 \mathrm{~m} l$ を添加した 後, 各消毒剤を Table 1 に示す所定の濃度となるように 加えて混合する。10 分間静置後, 海水 $2 l$ を入れたビー カーに移して稀釈 (200 倍) することにより作用を停止す る。

以上の不活化操作は, 恒温水槽を用いて $25^{\circ} \mathrm{C}$ の一定 温度で行った。

\section{4. 接種方法}

消毒剂で不活化処理後, 海水で稀釈された各ウイルス 液に 30 尾の供試エビを 2 時間浸漬して行った。

なお，供試エビの発育期は消毒剂の種類によって異な り, 塩素剤はミシス I 期, 塩化ベンゼトニウムとホルマ リンは P-3，その他の消毒剤は P-4 が用いられた。

\section{5. ウイルス不活化効果の判定方法}

接種された供試エビを水温 $24.0 \sim 28.1^{\circ} \mathrm{C}$ で 4 日間飼 育後, 無作為に採取した 10 尾の生鮮中腸腺について, 暗視野観察法 (桃山, 1983) により感染の有無を調べて効 果を判定した。

\section{結果および考察}

今回供試した消毒剤はいずれも BMN ウイルスに対 して不活化効果を有し, $25^{\circ} \mathrm{C} 10$ 分間作用では, それぞ

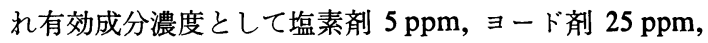
逆性石けん（塩化ベンザルコニウム，塩化ベンゼトニウ ム共) $100 \mathrm{ppm}$, ホルムアルデヒド $1,850 \mathrm{ppm}$ (ホルマリ ンとしては 0.5\%), エタノール 30\% で本ウイルスは完 全に不活化された (Table 1)。これら BMN ウイルスに 対して不活化効果を示す消毒剤の濃度は, カイコの NP ウイルスで得られている值（有賀, 1979; 宮島, 1979, 1986）に比べて著しく低いが，これは後者のほとんぞが 核多角体 (封入体) に包埋されたウイルスについて調べ

Table 1. Virucidal effect*1 of some disinfectants on BMN virus

\begin{tabular}{|c|c|c|c|c|c|c|}
\hline \multirow{3}{*}{$\begin{array}{l}\text { Concentra- } \\
\text { tion*2 }\end{array}$} & \multicolumn{5}{|c|}{ Disinfectants } & \multirow[b]{2}{*}{$\begin{array}{l}\text { Ethyl } \\
\text { alcohol }\end{array}$} \\
\hline & $\begin{array}{c}\text { Sodium } \\
\text { hypochlorite }\end{array}$ & Povidon-iodine & $\begin{array}{l}\text { Benzalkonium } \\
\text { chloride }\end{array}$ & $\begin{array}{l}\text { Benzethonium } \\
\text { chloride }\end{array}$ & Formalin & \\
\hline & \multicolumn{6}{|c|}{ Number of shrimp infected/number of shrimp examined } \\
\hline 200 & $0 / 10$ & & $0 / 10$ & $0 / 10$ & & \\
\hline 100 & $0 / 10$ & & $0 / 10$ & $0 / 10$ & $0 / 10$ & \\
\hline 90 & & & & & & $0 / 10$ \\
\hline 70 & & & & & & $0 / 10$ \\
\hline 50 & $0 / 10$ & $0 / 10$ & $6 / 10$ & $8 / 10$ & $0 / 10$ & $0 / 10$ \\
\hline 30 & & & & & & $0 / 10$ \\
\hline 25 & & $0 / 10$ & $7 / 10$ & $9 / 10$ & & \\
\hline 20 & & & & & & $10 / 10$ \\
\hline 10 & $0 / 10$ & $5 / 10$ & $8 / 10$ & $10 / 10$ & $2 / 10$ & $10 / 10$ \\
\hline 5 & $0 / 10$ & $10 / 10$ & $10 / 10$ & $10 / 10$ & $4 / 10$ & \\
\hline 1 & $10 / 10$ & $10 / 10$ & & & $9 / 10$ & \\
\hline Untreated & $10 / 10$ & $10 / 10$ & $10 / 10$ & $10 / 10$ & $9 / 10$ & $10 / 10$ \\
\hline
\end{tabular}

$* 110$ minutes exposure to disinfectants at $25^{\circ} \mathrm{C}$.

*2 Sodium hypochlorite and povidone-iodine: $\mathrm{ppm}$ as active principle-concentration of chlorine and iodine, respectively. Benzalkonium chloride and benzalthonium chloride: ppm. Formalin: $\% \times 100(1 \%$ of formalin is equivalent to $3,700 \mathrm{ppm}$ of formaldehyde solution). Ethyl alcohol: $\%$. 
られているためと思われる。核多角体を溶解して得た遊 離の NP ウイルスの不活化については, 0.5\% ホルマリ ン水 $26^{\circ} \mathrm{C}, 40$ 分 (古田, 1981) 户, さらし粉 5,000 倍 液 (有効塩素濃度約 $70 \mathrm{ppm}$ ), 30 分 (有賀, 1979) の值が 得られている。

通常, 水産増養殖に打沙消毒対象物は, 病原微生物 に污染された用・排水や飼育水槽 - 器具等の非生体材料 と, 受精卵等の生体材料の二つに大きく分けることがで きる。本症の発生に際しては, 病原体がウイルスであり, かつ, その病原性が極めて強いことから, 直ちに稚仔の 殺処分を兼祸て飼育水と生産タンク等を消毒し, 場内感 染等污染の拡大を防止することが生産現場においては特 に肝要であると思われる。この場合, 大量の飼育水を消 毒するには, 今回の実験で最も高いウイルス不活化効果 を示した安価な消毒剤である塩素剤が最も適している が，飼育水中に多量に含まれる有機物等による消毒剤の 活性の低下を考慮して扔く必要がある。その他の非生体 材料に対してもその種類に応じて，今回調べた各消毒剂 の不活化効果飞加元て, 有機物等による活性阻害, 金属 腐食作用, 経費等各消毒剤の長所, 短所 (古橋, 宮前, 1980）を考慮しながら使い分けることも必要である。

一方, 本症の主要な伝染源は親エビであり（桃山, 1988), 翼とともに飼育水中に排泄された BMN ウイル スは, ゾェア期幼生以後の摂䭒活動に伴って経口的に稚 仔の体内にとり込まれる可能性が強い*。サケ・マス類 ではウイルス病の予防にヨード剤による受精卵の消毒が 実用されているが (江草, 1978), クルマエビでは受精卵 に対する各消毒剤の有用性を検討するためには, 受精卵 に対する毒性を併せて調べることが必要であろう。

* 未発表

\begin{abstract}
謝辞
本研究を進めるにあたり, 有益な御助言と本報告の御 校閲をいただいた, 東京水産大学・佐野徳夫教授に厚く お礼申し上げます。

なお, 本研究費の一部は, 水産庁・魚病対策技術開発 研究委託費によったことを付記して感謝する。
\end{abstract}

\section{引用文献}

有賀久雄 (1979): 昆虫病理汎論. 養賢堂, 東京, pp. 648 . 江草周三 (1978)：魚の感染症。恒星社厚生閣, 東京, pp. 554.

福原敏彦 (1979): 昆虫病理学. 学会出版センター, 東 京, pp. 218.

古橋正吉・宮前卓之 (1980)：消毒薬の殺菌作用とその使 用法, 医科器械学叢書 3, 滅菌法・消毒法第 3 集. 文 光堂, 東京, 107-150.

古田要二 (1981): 家掻に抒ける核多角体のホルマリン㧍 よび熱処理による不活化. 虫系研究， 118, 105-112.

宮島成寿 (1979): 数種の消毒剤による家掻ウイルスの不 活化効果. 愛知県農業総合試験場研究報告, 11, 165168.

宮島成寿 (1986): 数種のアルコール及び次带塩素酸ナト リウムによる家虫ウイルスの不活化効果. 同誌, 18, 280-282.

桃山和夫 (1983)：クルマエビのバキュロウイルス性中腸 腺壊死症に関する研究-III. 仮診断法. 魚病研究, 17 (4), 263-268.

桃山和夫 (1988)：クルマエビの種苗生産時に発生するバ キュロウイルス性中腸腺壊死症 (BMN) の伝染源. 魚 病研究, 23(2), 105-110.

Momoyama, K. and T. Sano (1988): A method of experimental infection of kuruma shrimp larvae, Penaeus japonicus Bate, with baculoviral mid-gut gland necrosis (BMN) virus. J. Fish Diseases, 11(2), 105-111. 